\title{
Involvement of PDX-1 in activation of human insulin gene transcription
}

\author{
John Le Lay and Roland Stein \\ Department of Molecular Physiology and Biophysics, Vanderbilt University, 2001 West End Ave Nashville, Tennessee 37235, USA \\ (Requests for offprints should be addressed to R Stein; Email: roland.stein@vanderbilt.edu)
}

\begin{abstract}
Islet $\beta$ cell-specific transcription of the insulin gene is mediated through the binding of the islet-enriched PDX-1, BETA2, and MafA transcription factors to conserved 5 '-flanking region regulatory elements. However, additional non-conserved sequences within this region are also significant in regulating expression. Thus, PDX-1 binds to and activates the GG2 element located between nucleotides -145 and -140 of the human gene, while the corresponding, but non-identical, site in the rodent insulin genes are negatively regulated by the $\mathrm{Nkx} 2 \cdot 2$ transcription factor. Here, we show that despite binding PDX-1 approximately 20 -fold less effectively than the conserved insulin A3 and A1 sites in gel mobility shift assays, human GG2 appears to be more important for the activation of
\end{abstract}

transfected human insulin enhancer-driven reporter constructs in $\beta$ cell lines. Furthermore, functional interaction analysis in non-islet cell lines demonstrated that PDX-1 binding to GG2, A1, and A3 contributes to synergistic activation of insulin gene expression with MafA. Our analysis also illustrated the requirement of poorly conserved human sequences between -293 and -251 in mediating activity through the more upstream A3 binding site. Collectively these experiments have revealed distinct features in control of the human and rodent insulin genes by PDX-1, processes that may be involved in regulating insulin expression under both normal and diabetic conditions in humans.

Journal of Endocrinology (2006) 188, 287-294

\section{Introduction}

Insulin is exclusively synthesized in and released from the $\beta$ cells of pancreatic islets. Cell-type-restricted expression is conferred at the transcriptional level by a unique combination of regulators enriched in $\beta$ cells (Stein 2001). Transgenic studies in mice first demonstrated that approximately 350 base pairs (bp) upstream of the transcription start site of the non-allelic rat insulin I and II (rat I and II) genes mediate $\beta$ cell-specific expression (Hanahan 1985, Dandoy-Dron et al. 1991). These regions are $76 \%$ identical and display roughly $60 \%$ identity to the corresponding 5 '-flanking sequence of the human insulin gene, suggesting functional conservation between species. Indeed, the bases located between -353 and +1 of the human gene were subsequently found to be sufficient to drive cell-type selective transgene activity in vivo (Fromont-Racine et al. 1990). The ability of this region to restrict expression to $\beta$ cells has been demonstrated recurrently in transfection assays using transformed cell lines (Walker et al. 1983, Edlund T et al. 1985, Boam et al. 1990, Ahlgren et al. 1998, Edlund H 1998). Furthermore, this proximal $350 \mathrm{bp}$ control region is sufficient to confer responsiveness of insulin-driven reporter genes in both transfected islets (German et al. 1990, Odagiri et al. 1996) and cell lines (Sharma \& Stein 1994, Sharma et al. 1995) to glucose, the most important metabolic effector of $\beta$ cell function. Altogether, these studies clearly demonstrated the importance of sequences proximal to the insulin promoter in regulating $\beta$ cell-specific and glucoseresponsive expression.

Both cell-restricted and glucose-inducible expression of mammalian insulin genes appear to be controlled, at least in part, by the effects of islet-enriched transcriptional activators binding conserved C, E, and A elements (Stein 2001). These elements reside between -350 to $-90 \mathrm{bp}$, a region with $\beta$ cell-specific enhancer-like properties (Edlund T et al. 1985, Fromont-Racine et al. 1990). The C1 element, located between bp -125 and -116 of the human gene, binds the basic leucine-zipper factor MafA (Matsuoka et al. 2003), while E1 (bp -111/-102) is a site for regulation by a heterodimer of ubiquitous E47 and the islet-enriched BETA2 basic helix-loop-helix containing proteins (Naya et al. 1995), and A1 (bp -83/-75) and A3 (bp -216/-207) are critical sites of control by the PDX1 homeodomain protein (Ohlsson et al. 1993, Petersen et al. 1994). While these elements appear to be principal contributors to cell-exclusive and glucose-responsive activation of insulin gene transcription, additional speciesspecific cis-acting sequences have also been implicated 
in regulation (Boam et al. 1990, Sander et al. 1998, Okita et al. 1999, Bartoov-Shifman et al. 2002, Oetjen et al. 2003). For example, the human insulin GG2 element located between bp -145 and -140 is a site of positive regulation by $\mathrm{PDX}-1$, despite lacking a characteristic homeodomain factor TAAT core binding motif (Le Lay et al. 2004). In contrast, the corresponding GG2 element of the rat and mouse insulin genes are negatively regulated by the islet-enriched factor $\mathrm{Nkx} 2 \cdot 2$, with species-selective binding resulting from differences at nucleotides -144 and -141 in the human gene (Cissell et al. 2003). The human insulin gene also possesses a unique glucose- and islet cell-specific control region spanning bp -292 to -243 , termed the $\mathrm{Z}$ region (Sander et al. 1998), which is poorly conserved in the rat and mouse genes.

In the present study, we first compared the contribution of PDX-1 binding at GG2 relative to the conserved A1 and A3 sites in human insulin gene activation. Although GG2 displayed a lower PDX-1 binding affinity in gel shift assays, it was more critical to human insulin activation in $\beta$ cell transfection assays. GG2 also contributed to synergistic activation by PDX-1 and MafA. Moreover, the ability of PDX-1 to activate through the human A3 element was found to be dependent upon upstream sequences from $b p-293$ to -251 , an area of poor sequence homology spanning the unique human $\mathrm{Z}$ control domain. These studies have revealed distinctions in control of the human and rodent insulin genes by PDX-1, features that may be of importance in vivo.

\section{Materials and Methods}

\section{DNA constructs}

The human insulin enhancer-driven luciferase (Luc) reporter containing wild-type (WT) $5^{\prime}$ control sequences from -251 to +10 (-251 Luc WT) has been described previously (Sharma et al. 1995). The human insulin (Ins) A1 (-83/-75 bp), GG2 (-145/-140), and A3 (-216/ $-207 \mathrm{bp}$ ) elements were mutated in $-251 \mathrm{Luc}$ using the QuikChange site-directed mutagenesis kit (Stratagene, La Jolla, CA, USA) with the following primers: A1 mutant (mut) $\left({ }^{-97}\right.$ CCCCCACCCCAGGCCCTCCTGGGCCA GGCGGCAGGGGTTG $\left.{ }^{-58}\right)$, GG2 mut $\left({ }^{-160}\right.$ CAGACCC AGCACCAGGGAACTGGTCCGGAAATTGCAGC $\left.\mathrm{C}^{-122}\right)$, and A3 mut $\left({ }^{-232}\right.$ GGCCCCTGGTTAAGACTC TCCTGACCCGCTGGTCCTGAGG ${ }^{-193}$ ). Mutated sequences are underlined. Human insulin WT and mutant versions of -342 Luc and -293 Luc were made by first PCR amplifying bp -342 to -237 and $b p-293$ to -237 from human genomic DNA using puReTaq ReadyTo-Go PCR beads (Amersham) for 35 cycles $\left(95^{\circ} \mathrm{C}\right.$ for $30 \mathrm{~s}, 65^{\circ} \mathrm{C}$ for $30 \mathrm{~s}$, and $72{ }^{\circ} \mathrm{C}$ for $1 \mathrm{~min}$ ) with primers corresponding to human ins -342 sense- Kpn I (5'TTTAAAGGTACCTGCAGCCTCCAGCTCTCCTGG$\left.3^{\prime}\right)$ or human ins -293 sense-Kpn I (5'-ATTATTGGTAC
CGGGCTTTGCTCTCCTGGAGAC-3') and human ins -237 anti-sense-Msc I (5'-TATATATGGCCAGAC CTGTCCCTGCTCAC-3'). The Kpn I - Msc I-digested fragments were then subcloned into -251 Luc WT, -251 Luc (A1 mut), -251 Luc (GG2 mut), and -251 Luc (A3 mut). Z/A3 TK-CAT was constructed from bp -293 to -192 of human insulin that was generated by PCR amplification using -293 sense-Hind III (5'-ATTGCT AAGCTTGGGCTTTGCTCTCCTGGAGAC-3') and human ins -192 anti-sense Xba I (5'-ATTATTTCTAG ATCCTCAGGACCAGCGGGTC-3'), and then subcloned into the Hind III-Xba I-site of chloramphenicol acetyltransferase (CAT) reporter pTK-(An) (Jacoby et al. 1989). The A3 site was mutated by site-directed mutagenesis using the A3 mut primer and its compliment. Partial restriction enzyme digest and DNA sequencing analysis confirmed the correctness of the constructs.

The rat II insulin-driven luciferase reporters containing wild type sequences from -238 to $+2(-238$ Luc WT) and a PDX-1 binding-deficient A3 mutant (-238 Luc A3 mut) (Sharma et al. 1995), as well as cytomegalovirus (CMV) enhancer-driven MafA (pcDNA-MafA) (Matsuoka et al. 2003) and PDX-1 (pcDNA-PDX-1) (Peshavaria et al. 1997) expression vectors have been described previously.

\section{Gel mobility shift assays}

Nuclear extracts were prepared from cell lines using procedures previously described by Schreiber et al. (1989). DNA binding analysis was performed with doublestranded oligonucleotides to human Ins A1 ( ${ }^{-92}$ ACCCCA GGCCCTAATGGGCCAGGCGG ${ }^{-67}$ ), human Ins GG2 $\left({ }^{-155}\right.$ CCAGCACCAGGGAAATGGTCCGGAAA $\left.^{-130}\right)$, human Ins A3 ( ${ }^{-225}$ GGTTAAGACTCTAATGACCCG CTGGT $^{-200}$ ) and Nkx2.2 consensus (GGTTTTTAAGT GGTTTTTGGG) (Watada et al. 2000). The annealed A1 oligonucleotide was labeled with $\left[\gamma^{32} \mathrm{P}\right]$ ATP using T4 polynucleotide kinase.

Standard binding reactions ( $25 \mu$ l total volume) were conducted at $4{ }^{\circ} \mathrm{C}$ for $30 \mathrm{~min}$ with $10 \mu \mathrm{g}$ nuclear extract and 400 fmole of radiolabeled probe in binding buffer containing $10 \mathrm{mM}$ Tris ( $\mathrm{pH}$ 8), $100 \mathrm{mM} \mathrm{NaCl}, 1 \mathrm{mM}$ EDTA, 2 mM DTT, 10\% glycerol, and $1 \mu \mathrm{g}$ poly(dI-dC). Competition assays were performed under the same conditions, except that an excess of competitor DNA was included in the reaction along with the probe prior to the addition of protein. Protein-DNA complexes were resolved on $5 \%$ non-denaturing polyacrylamide gels run in $1 \times$ TGE buffer $(50 \mathrm{mM}$ Tris, $380 \mathrm{mM}$ glycine, $2 \mathrm{mM}$ EDTA) at room temperature. Gels were then dried and binding complexes were visualized by autoradiography and quantitated by densitometric scanning.

\section{Cell culture and transfections}

Monolayer cultures of $\beta$ TC-3 (mouse) and HeLa (human) cell lines were maintained as described previously 
(Zhao et al. 2000). The day before transfection, $\beta$ TC-3 $\left(10^{6}\right)$ and HeLa $\left(0 \cdot 2 \times 10^{6}\right)$ cells were transferred into $35 \mathrm{~mm}$ wells. The lipofectamine reagent was used to introduce pcDNA3-MafA $(0 \cdot 25 \mu \mathrm{g})$, pcDNA3-PDX-1 $(0.25 \mu \mathrm{g})$, pcDNA3 control $(0.25 \mu \mathrm{g})$, WT or mut Insulin-Luc $(0.25 \mu \mathrm{g})$, phRL-TK $(10 \mathrm{ng})$, pTK-CAT $(1 \mu \mathrm{g})$, WT or mut Insulin-CAT $(1 \mu \mathrm{g})$, and pRSV-Luc $(0.5 \mu \mathrm{g})$. Dual luciferase (Promega), CAT (Nordeen et al. 1987), and luciferase (de Wet et al. 1987) enzymatic assays were performed on cell extracts prepared 40 to $48 \mathrm{hr}$ after transfection. The Luc activity from phRL-TK and pRSVLuc served as controls for transfection efficiency in dual luciferase and CAT assays, respectively. The statistical significance of normalized Luc and CAT activities were determined by Student's $t$-test. Each experiment was carried out three times with two independently isolated DNA preparations.

\section{Results}

GG2 element binds PDX-1 less effectively than conserved $A 1$ and $A 3$

PDX-1 activates human GG2, but not the corresponding element in the rodent insulin I or II genes (Cissell et al. 2003, Le Lay et al. 2004). Interestingly, the human site lacks the TAAT core motif commonly associated with homeodomain protein binding. To directly compare the efficacy with which this non-conserved, atypical site binds PDX-1 relative to the conserved and canonical human A1 and A3 elements, competition analyses in gel mobility shift assays were performed. GG2 was less capable of competing for PDX-1 binding to the A1 probe than A1 and $\mathrm{A} 3$ in $\beta$ TC-3 nuclear extracts (Fig. 1A). Quantitation of the PDX-1 binding complex revealed that, respectively, A1 and A3 bound approximately 15- and 25-fold better than GG2 (Fig. 1B). Furthermore, the Nkx2.2 consensus sequence, used during the biochemical isolation and identification of PDX-1 as the GG2 site activator (Le Lay et al. 2004), was found to compete for PDX-1 binding nearly 10-fold more effectively than GG2, despite itself lacking a TAAT core (Fig. 1). Collectively, these results demonstrated the ability of PDX-1 to bind a variety of $\mathrm{A} / \mathrm{T}$-rich sequences in vitro.

\section{PDX-1 binding at GG2 is critical to human insulin expression in $\beta$ cells}

Although the exact mechanism(s) involved in mediating synergistic transcriptional activation of the insulin gene by PDX-1, MafA, and BETA 2 is unclear, functional interactions between these factors is important in control. For example, although PDX-1 alone is a poor stimulator of insulin enhancer-driven reporter expression, high-level co-operative activation is observed upon co-transfection with MafA in non- $\beta$ cells (Zhao et al. 2005).
To compare the contribution of GG2, A1, and A3 to PDX-1/MafA-mediated activation of the human insulin gene, expression constructs for PDX-1 and MafA were co-transfected into HeLa cells with WT and PDX-1 binding-deficient site mutant versions of -251 Luc, a luciferase reporter driven by the nucleotides between -251 and +10 of the human insulin gene. As expected, none of the reporters significantly responded to PDX-1, but each was activated similarly by MafA alone (Fig. 2). Synergistic stimulation of -251 WT Luc was observed when PDX-1 and MafA were combined, however, the level of activation was attenuated by each of the PDX-1 site mutants (Fig. 2). These results indicated that PDX-1 binding to GG2 is involved in potentiating transcription of the human insulin gene.

To assess the relative importance of the GG2, A1, and A3 PDX-1 binding sites to human insulin gene expression in $\beta$ cells, the WT and mutant versions of -251 Luc were transfected into $\beta$ TC-3 cells. The GG2 mutant was approximately $75 \%$ less active than WT, while A1 mutant activity was only reduced by $55 \%$ despite binding PDX-1 much more effectively in gel shift assays (Fig. 3). In contrast, mutation of the high-affinity A3 element resulted in slightly enhanced activity compared with the WT construct (Fig. 3). These results indicate that PDX-1 binding to GG2 is critical to human insulin gene transcription in islet $\beta$ cells.

\section{Z-Region sequences mediate PDX-1 activation of the human insulin gene}

It was surprising that the A3 mutant did not reduce -251 Luc activity, since preventing PDX-1 binding at this site severely diminishes activation of reporter constructs driven by either the corresponding sequences of the rat II insulin gene (-238 Luc) (Fig. 3), or human insulin control sequences extending to $\mathrm{bp}-342$ (Petersen et al. 1994). Interestingly, the -342 to -252 region of human is not well conserved with rodent insulin $(\sim 50 \%$ identical $)$, yet contains elements that contribute to $\beta$ cell-selective and glucose-responsive activation of human insulin gene expression (Pino et al. 2005), including the $Z$ control region between bp -292 and -243 (Sander et al. 1998). Consistent with a role in transcriptional activation, human insulin enhancer-driven reporters containing control sequences extending to nucleotides -342 and -293 were approximately 4- to 5-fold more active than -251 Luc (Fig. 4).

The effects of the PDX-1 site mutants on the extended -342 Luc and -293 Luc constructs were also measured in transfected $\beta$ TC-3 cells and compared with their impact on -251 Luc activity. The A1 and GG2 mutations reduced -342 Luc and -293 Luc activity even more dramatically than in -251 Luc (Fig. 4C), suggesting that PDX-1 regulation is influenced by functional interactions with both distal and proximal control factors. Additionally, extending the control sequence to $\mathrm{bp}-293$ and $\mathrm{bp}-342$ 


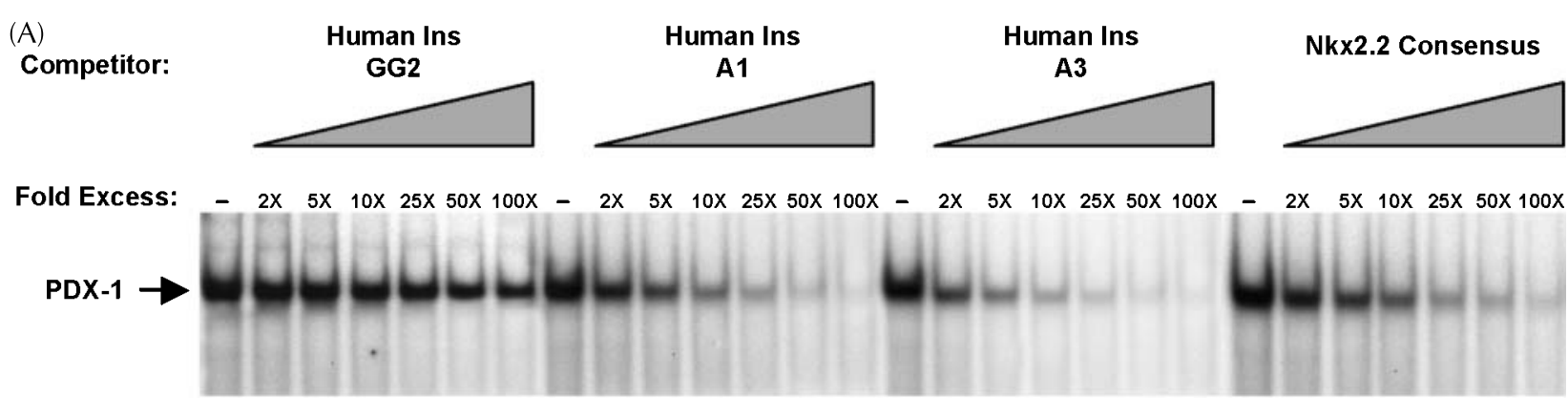

(B)

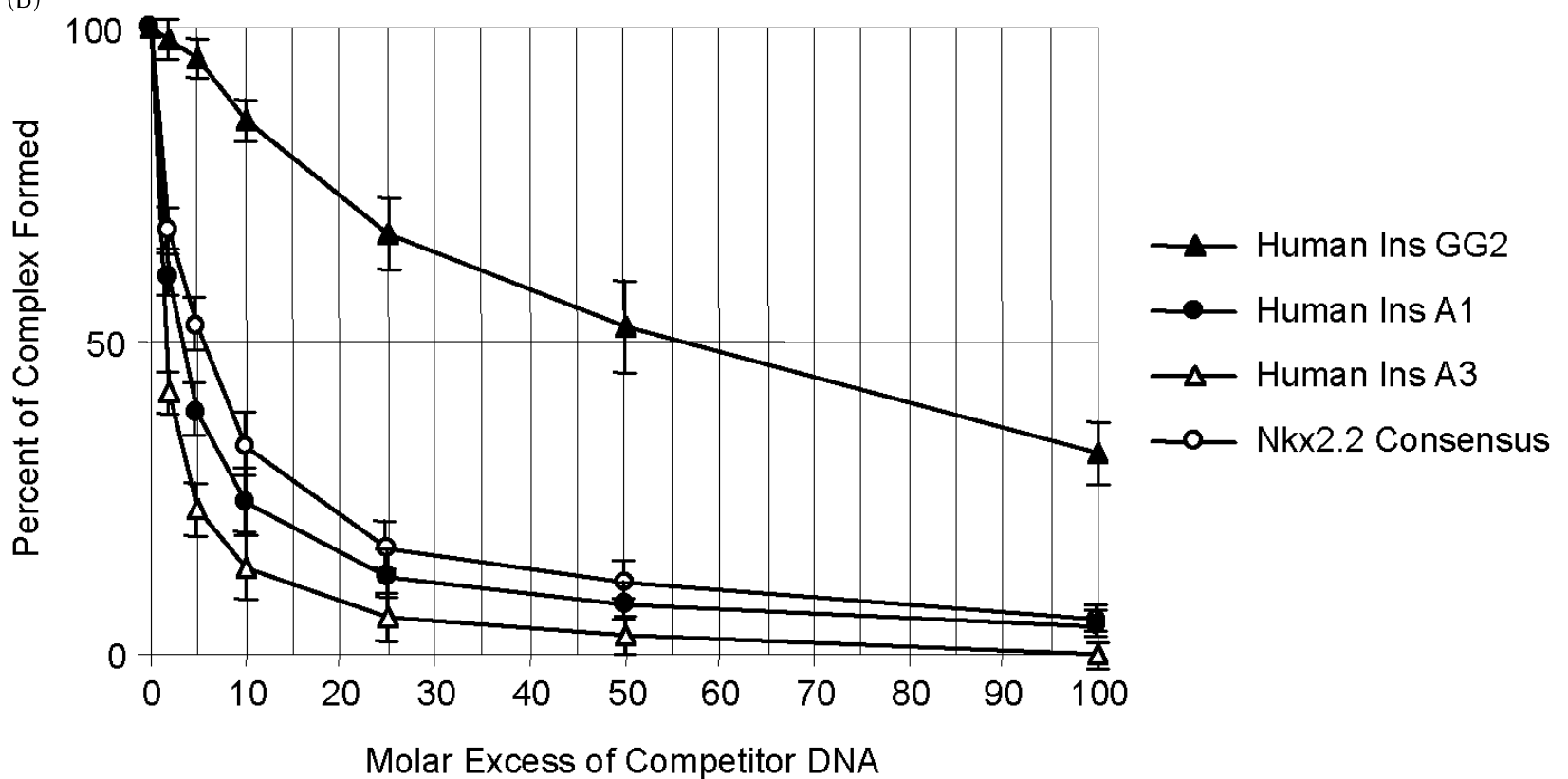

Figure 1 The human GG2 element binds PDX-1 less effectively than A1 and A3. (A) Binding to the human insulin (Ins) A1 probe in $\beta$ TC-3 nuclear extract was evaluated in the presence of the indicated unlabelled competitors. (B) The amount of PDX-1 binding activity was determined by densitometric scanning and plotted relative to the amount of binding complex formed in the absence (-) of competitor DNA. The values presented are the average of three experiments \pm S.E.M.

restored the sensitivity of these reporters to the mutation of A3 that prevents PDX-1 binding and activation at that site (Fig. 4C). Furthermore, the activity of the A3 mutants was reduced to a similar level ( $\sim 45 \%$ of WT; Fig. $4 \mathrm{C})$, specifically implicating the involvement of factors associated with $\mathrm{Z}$ region in modulating PDX-1 activation through the A3 site. To test this proposal, the region spanning bp -293 to -192 , which contains both the Z region and the A3 site, was ligated upstream of the herpes virus thymidine kinase (TK) promoter in the pTK-CAT reporter vector (A3/Z TK-CAT). When transfected into $\beta T C-3$ cells, A3/Z TK-CAT was approximately 2-fold more active than the empty TK-CAT vector (Fig. 5). Significantly, bp -293/-192 activation was impaired upon mutating the A3 site, demonstrating the involvement of PDX-1 in expression of the reporter (Fig. 5). These results not only indicate that PDX-1 is important in $\mathrm{Z}$ region-mediated activation of the human insulin gene, but it also likely reveals another fundamental difference in how PDX-1 activates human versus rodent insulin gene expression.

\section{Discussion}

PDX-1 is a key co-ordinator of processes involved in islet $\beta$ function and pancreas development (Ahlgren et al. 1996). This factor was first isolated and has been principally characterized in the context of its integral role in insulin gene transcription. Thus, PDX-1 alone is capable of activating endogenous insulin expression in non- $\beta$ cells (Serup et al. 1996, Watada et al. 1996), while siRNA knockdown of PDX-1 in $\beta$ cell lines or primary islets decreases insulin mRNA levels (Iype et al. 2005). 


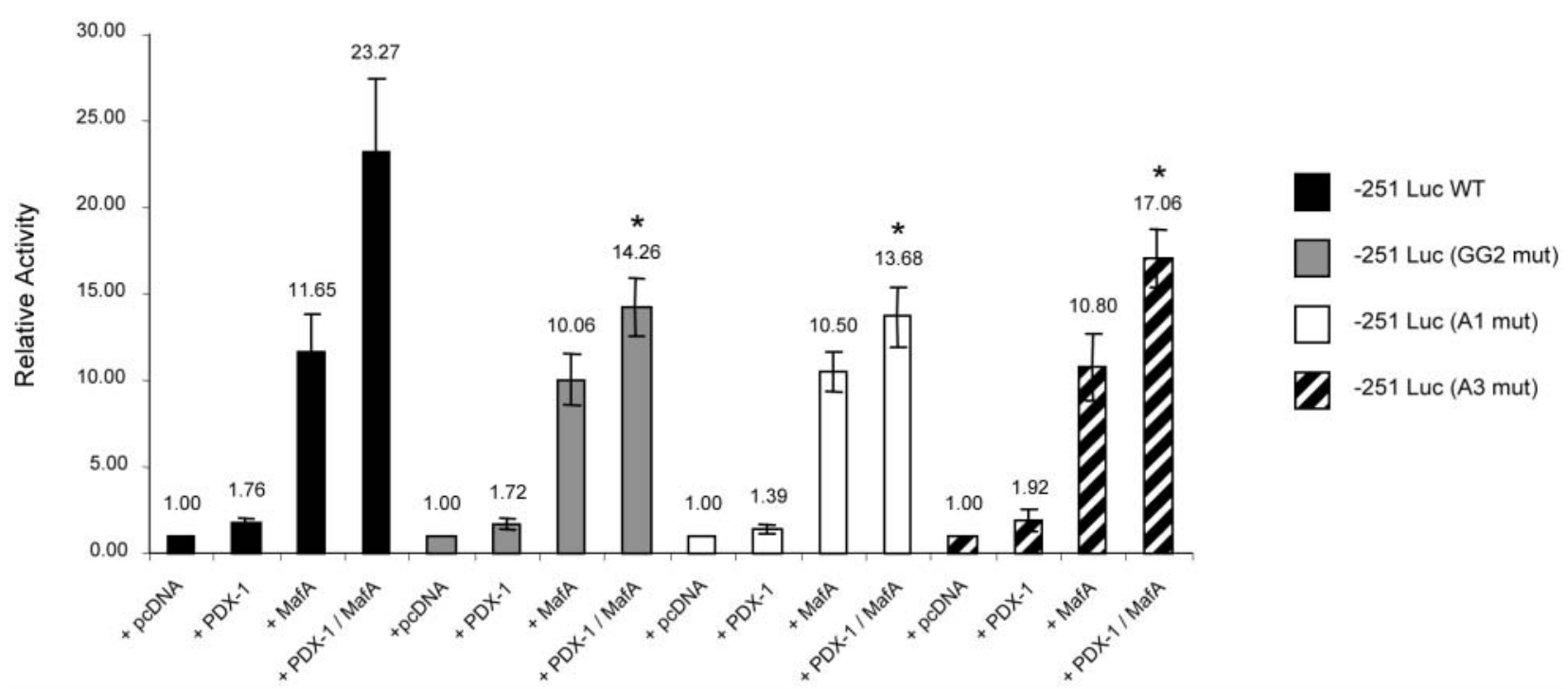

Figure 2 Cooperative activation of human insulin-driven reporter expression by MafA and PDX-1 is impaired in by the GG2, A1 and A3 mutations. HeLa cells were transfected with the wild type (WT) or mutated (mut) human -251 Luc reporters along with pcDNA control or expression vectors for PDX-1 and/or MafA. Reporter activity \pm S.E.M. is presented relative to the activity of the respective reporter construct co-transfected with the pcDNA empty vector control. Asterisks denote that co-operative activation was significantly reduced between -251 WT and the -251 mut constructs $(P<0 \cdot 005)$.

PDX-1 also regulates glucose-responsive activation of the insulin gene (Petersen et al. 1994, Marshak et al. 1996). Although it is unclear how glucose stimulates PDX-1mediated activation, interactions with other regulatory proteins are likely to be influenced by post-translational modifications of this factor. In the current study, we have shown the importance to human insulin transcription of PDX-1 binding to the novel GG2 site, and illustrated how communication between conserved A3/PDX-1 and the human Z-region impacts upon expression. These results also exemplify how PDX-1 activates human insulin differently from the more extensively characterized

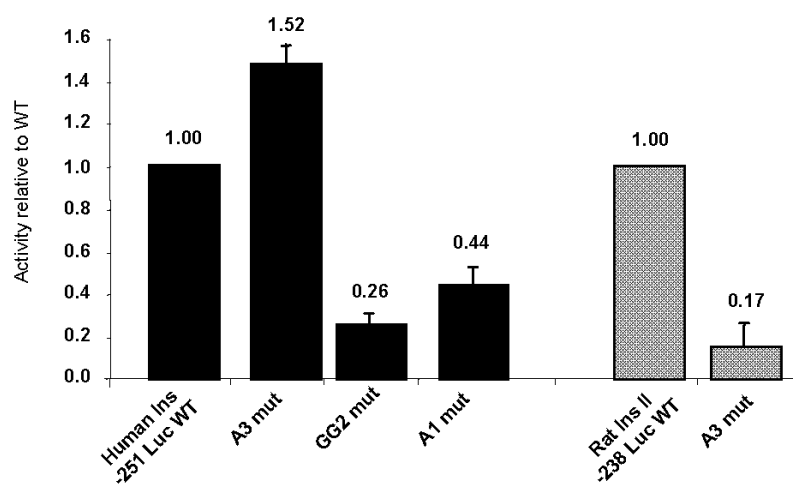

Figure 3 The selective effect of PDX-1 site mutants on human -251 Luc reporter activity in $\beta$ cells. $\beta$ TC-3 cells were transfected with the wild type (WT) or mutated (mut) human -251 Luc, or rat II -238 Luc reporter constructs. The activity of -251 Luc and -238 Luc mutants are presented relative to -251 Luc WT or -238 Luc WT, respectively. rodent genes, which may be of significance in control under normal and diabetic conditions in humans.

PDX-1 binds very effectively to the canonical insulin A1 and A3 elements in gel shift assays (Ohlsson et al. 1993, Peshavaria et al. 1994, Petersen et al. 1994), but can also interact with sites lacking the TAAT motif commonly associated with homeodomain protein binding, like human GG2 (GGAAAT) and the $\mathrm{Nkx} 2 \cdot 2$ consensus (TTAAGT) (Le Lay et al. 2004). Our competition studies indicate that PDX-1 binds to A1 or A3 roughly 15- and 25-fold better than GG2, but only 2- to 3-fold more effectively that the $\mathrm{Nkx} 2 \cdot 2$ site (Fig. 1). These findings most likely reflect the involvement of non-core flanking sequences in DNA binding recognition as proposed by Liberzon et al. (2004), and affirms that PDX-1 binding in vitro is not absolutely dependent on a TAAT core sequence. Unfortunately, it is not possible to directly determine if PDX-1 binds within the GG2 region of the human insulin gene in vivo due to the unavailability of human islet $\beta$ cells. No suitable, well-characterized human $\beta$ cell lines have been developed for this type of analysis, while the use of human islets is impractical, largely due to short supply. Furthermore, the method of choice for this type of study is the chromatin immunoprecipitation assay, which can detect PDX-1 binding within the endogenous mouse insulin genes (presumably to conserved A1 and A3) (Cissell et al. 2003), but is unable to distinguish occupancy of A3 from A1 (or GG2 in humans) because of their close proximity.

Despite binding to PDX-1 relatively poorly in vitro, a dysfunction mutation in GG2 was more detrimental to 


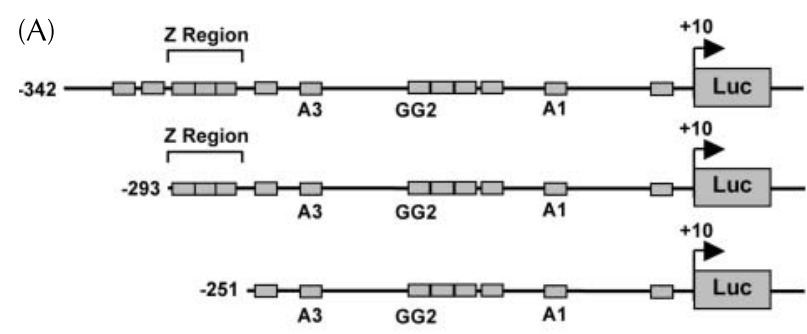

(B)

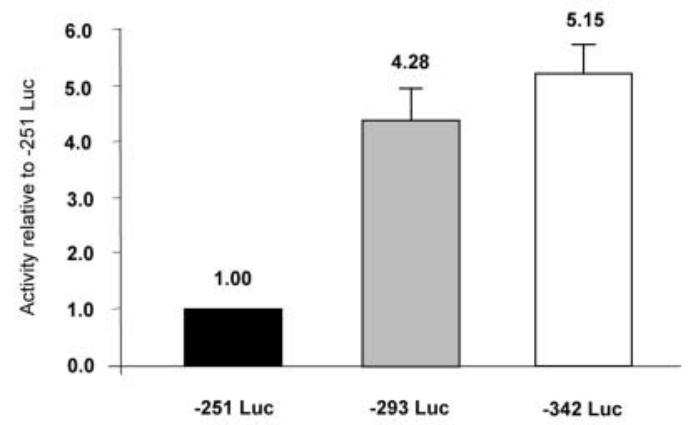

(C)

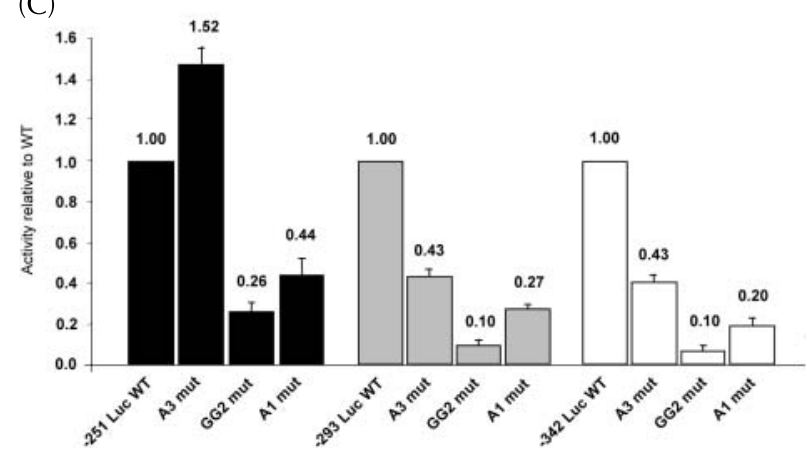

Figure 4 Human insulin sequences between -342 and -251 are involved in PDX-1-mediated activation. (A) Schematic depicting -342 Luc, -293 Luc, and -251 Luc reporter constructs, with an emphasis on the $A 1, G G 2, A 3$, and $Z$ region control sequences within them. Several distinct elements appear to regulate $Z$ region activity (Cissell et al. 1998, Pino et al. 2005). (B) $\beta$ TC-3 cells were transfected with -342 Luc, -293 Luc, or -251 Luc with activity presented relative to -251 Luc S.E.M. (C) $\beta$ TC-3 cells were transfected with WT or mut versions of -342 Luc, -293 Luc, and -251 Luc reporters. Mutant reporter activity is presented relative to their respective WT construct \pm S.E.M.

human insulin gene enhancer-driven reporter activity than the A1 and A3 mutants in transfected $\beta$ cells. Indeed, others have found that homeodomain-containing proteins function in a very precise and specific manner in vivo in spite of relatively low binding specificity and affinity in vitro (Mann 1995, Biggin \& McGinnis 1997). One explanation for this apparent paradox is that target specificity is conferred through co-operation with other regulatory factors. This model is consistent with studies indicating that direct interactions between PDX-1, BETA2/E47 and MafA are important for maximal insulin

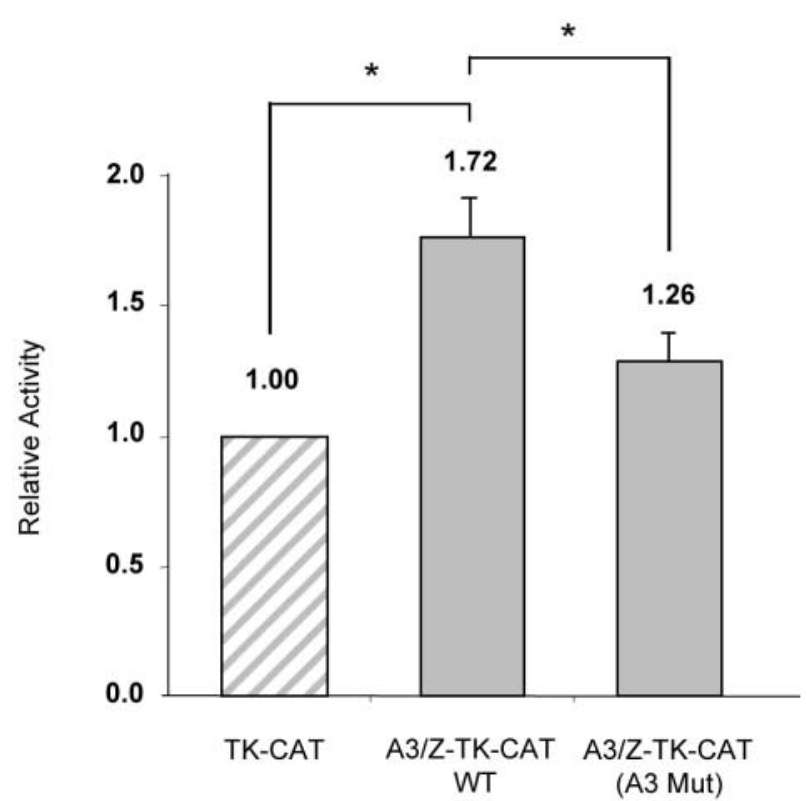

Figure 5 The $Z$ region is involved in mediating PDX- 1 activation of the $\mathrm{A} 3$ site. WT and $\mathrm{A} 3$ mutant sequences spanning the $Z$ region and A3 site (bp-293/-192; A3/Z) were ligated upstream of a minimal thymidine kinase (TK) promoter driving the CAT reporter. $\beta T C-3$ cells were transfected with TK-CAT, A3/Z-TK-CAT WT, or A3/Z-TK-CAT (A3 mut). Reporter activity is presented relative to TK-CAT \pm S.E.M. The asterisk denotes that a significant difference was found between the indicated points $(P<0 \cdot 0001)$.

gene expression (Peers et al. 1994, Qiu et al. 2002, Zhao et al. 2005). Our data showing that mutations in each of the PDX-1 binding sites within the human insulin control region negatively impact synergistic activation mediated by PDX-1 and MafA support this proposal. However, PDX-1 and MafA were recently found to only synergistically activate rodent, and not human, insulin enhancerdriven reporter expression (Docherty et al. 2005), a dissimilarity due possibly to differences in the human control sequences driving reporter expression and/or variations in the assayed cell lines.

The importance of PDX-1 interactions with other human insulin activator factors was also observed upon comparing mutant site-responsiveness of $-342 \mathrm{Luc}$ and -293 Luc to -251 Luc. Most strikingly, mutation of A3 did not have a detrimental impact on -251 Luc activity, a result that contrasts with PDX-1 regulation by the corresponding rodent insulin control region, wherein activity is compromised upon mutation (Peshavaria et al. 1994) (e.g. see -238 Luc in Fig. 2). A3 mutant sensitivity was restored by $\mathrm{Z}$ control region sequences located between nucleotides -293 and -251 , an area poorly conserved with rodents. In fact, A3-dependent regulation was not only observed in the -342 Luc and -293 Luc constructs, but also in activation by the isolated Z/A3 region (Fig. 5). Interestingly, GG2 and A1 mutant expression was more 
severely effected in the -342 Luc and -293 Luc backgrounds than in -251 Luc in $\beta$ cells (Fig. 4C), implying that interactions between PDX-1 and factors binding within the distinctive $Z$ region are fundamental to human insulin transcription. The activity of the $Z$ region appears to be regulated by several distinct control elements, including a glucose-responsive factor unique to islets (Sander et al. 1998). Unfortunately, the factors controlling expression from this region have not been identified despite the presence of potential $\mathrm{E}$ box and palindromic regulatory elements (Sander et al. 1998, Pino et al. 2005).

Despite the awareness that deregulation of insulin gene expression contributes to diabetes in humans, a disproportionate focus has been directed toward using rodent insulin genes as the model of mammalian insulin transcription. The observed sequence homology between the human and rodent insulin regulatory regions $(\sim 60 \%)$ has led to the misconception that their mechanisms of control are also conserved, when in fact the arrangement of cis-acting elements are quite distinct between species (Read et al. 1993, Clark et al. 1995, Le Lay et al. 2004, Matsuoka et al. 2004, Neve et al. 2005). In addition, a polymorphic region unique to the human insulin gene termed the VNTR (variable number of tandem repeats), which extends $5^{\prime}$ from bp -360 , has been mapped as a susceptibility locus for Type I diabetes (Bennett et al. 1995). In light of these dissimilarities, our studies emphasize novel ways the human and rodent insulin genes are regulated by PDX-1, a factor whose relationship to pancreas formation and $\beta$ cell function in humans is well documented (Macfarlane et al. 1999). Work such as this underscores unique regulatory features of the human insulin gene, and provides insight into how $\beta$ cell function is regulated under normal and diabetic conditions.

\section{Acknowledgements}

We thank Eva Henderson for providing technical support.

\section{Funding}

This work was supported by grants from the National Institutes of Health (DK50203 to R S), the Juvenile Diabetes Research Foundation (1-2002-775 to R S), and the Vanderbilt Molecular Endocrinology Training Program (5 T 32 DK07563 to J L). Partial support was also provided to the Molecular Biology Core Laboratory by the Vanderbilt University Diabetes Research and Training Center (P60 DK20593). The authors declare that there is no conflict of interest that would prejudice the impartiality of this scientific work.

\section{References}

Ahlgren U, Jonsson J \& Edlund H 1996 The morphogenesis of the pancreatic mesenchyme is uncoupled from that of the pancreatic epithelium in IPF1/PDX1-deficient mice. Development 122 1409-1416.

Ahlgren U, Jonsson J, Jonsson L, Simu K \& Edlund H 1998 $\beta$-cell-specific inactivation of the mouse Ipf1/Pdx1 gene results in loss of the beta-cell phenotype and maturity onset diabetes. Genes Development 12 1763-1768.

Bartoov-Shifman R, Hertz R, Wang H, Wollheim CB, Bar-Tana J \& Walker MD 2002 Activation of the insulin gene promoter through a direct effect of hepatocyte nuclear factor 4 alpha. Journal of Biological Chemistry 277 25914-25919.

Bennett ST, Lucassen AM, Gough SC, Powell EE, Undlien DE, Pritchard LE, Merriman ME, Kawaguchi Y, Dronsfield MJ, Pociot F et al. 1995 Susceptibility to human type 1 diabetes at IDDM2 is determined by tandem repeat variation at the insulin gene minisatellite locus. Nature Genetics 9 284-292.

Biggin MD \& McGinnis W 1997 Regulation of segmentation and segmental identity by Drosophila homeoproteins: the role of DNA binding in functional activity and specificity. Development 124 4425-4433.

Boam DS, Clark AR \& Docherty K 1990 Positive and negative regulation of the human insulin gene by multiple trans-acting factors. Journal of Biological Chemistry 265 8285-8296.

Cissell MA, Zhao L, Sussel L, Henderson E \& Stein R 2003 Transcription factor occupancy of the insulin gene in vivo. Evidence for direct regulation by $\mathrm{Nkx} 2 \cdot 2$. Journal of Biological Chemistry 278 751-756.

Clark AR, Wilson ME, Leibiger I, Scott V \& Docherty K 1995 A silencer and an adjacent positive element interact to modulate the activity of the human insulin promoter. European Journal of Biochemistry 232 627-632.

Dandoy-Dron F, Monthioux E, Jami J \& Bucchini D 1991 Regulatory regions of rat insulin I gene necessary for expression in transgenic mice. Nucleic Acids Research 19 4925-4930.

de Wet JR, Wood KV, DeLuca M, Helinski DR \& Subramani S 1987 Firefly luciferase gene: structure and expression in mammalian cells. Molecular and Cellular Biology 7 725-737.

Docherty HM, Hay CW, Ferguson LA, Barrow J, Durward E \& Docherty K 2005 Relative contribution of PDX-1, MafA and $\mathrm{E} 47 /$ beta2 to the regulation of the human insulin promoter. Biochemistry Journal 389 813-820.

Edlund H 1998 Transcribing pancreas. Diabetes 47 1817-1823.

Edlund T, Walker MD, Barr PJ \& Rutter WJ 1985 Cell-specific expression of the rat insulin gene: evidence for role of two distinct $5^{\prime}$ flanking elements. Science 230 912-916.

Fromont-Racine M, Bucchini D, Madsen O, Desbois P, Linde S, Nielsen JH, Saulnier C, Ripoche MA, Jami J \& Pictet R 1990 Effect of $5^{\prime}$-flanking sequence deletions on expression of the human insulin gene in transgenic mice. Molecular Endocrinology 4 669-677.

German MS, Moss LG \& Rutter WJ 1990 Regulation of insulin gene expression by glucose and calcium in transfected primary islet cultures. Journal of Biological Chemistry 265 22063-22066.

Hanahan D 1985 Heritable formation of pancreatic beta-cell tumours in transgenic mice expressing recombinant insulin/simian virus 40 oncogenes. Nature 315 115-122.

Iype T, Francis J, Garmey JC, Schisler JC, Nesher R, Weir GC, Becker TC, Newgard CB, Griffen SC \& Mirmira RG 2005 Mechanism of insulin gene regulation by the pancreatic transcription factor Pdx-1: application of pre-mrna analysis and chromatin immunoprecipitation to assess formation of functional transcriptional complexes. Journal of Biological Chemistry 280 16798-16807.

Jacoby DB, Zilz ND \& Towle HC 1989 Sequences within the $5^{\prime}$-flanking region of the S14 gene confer responsiveness to glucose 
in primary hepatocytes. Journal of Biological Chemistry $26417623-17626$.

Le Lay J, Matsuoka TA, Henderson E \& Stein R 2004 Identification of a novel PDX-1 binding site in the human insulin gene enhancer. Journal of Biological Chemistry 279 22228-22235.

Liberzon A, Ridner G \& Walker MD 2004 Role of intrinsic DNA binding specificity in defining target genes of the mammalian transcription factor PDX1. Nucleic Acids Research 32 54-64.

Macfarlane WM, Frayling TM, Ellard S, Evans JC, Allen LI, Bulman MP, Ayres S, Shepherd M, Clark P, Millward A et al. 1999 Missense mutations in the insulin promoter factor- 1 gene predispose to type 2 diabetes. Journal of Clinical Investigations 104 R33-39.

Mann RS 1995 The specificity of homeotic gene function. Bioessays 17 855-863.

Marshak S, Totary H, Cerasi E \& Melloul D 1996 Purification of the beta-cell glucose-sensitive factor that transactivates the insulin gene differentially in normal and transformed islet cells. PNAS $\mathbf{9 3}$ 15057-15062.

Matsuoka TA, Zhao L, Artner I, Jarrett HW, Friedman D, Means A \& Stein R 2003 Members of the large Maf transcription family regulate insulin gene transcription in islet beta cells. Molecular and Cellular Biology 23 6049-6062.

Matsuoka TA, Artner I, Henderson E, Means A, Sander M \& Stein R 2004 The MafA transcription factor appears to be responsible for tissue-specific expression of insulin. PNAS 101 2930-2933.

Naya FJ, Stellrecht CM \& Tsai MJ 1995 Tissue-specific regulation of the insulin gene by a novel basic helix-loop-helix transcription factor. Genes Development 9 1009-1019.

Neve B, Fernandez-Zapico ME, Ashkenazi-Katalan V, Dina C, Hamid YH, Joly E, Vaillant E, Benmezroua Y, Durand E, Bakaher $\mathrm{N}$ et al. 2005 From The Cover: Role of transcription factor KLF11 and its diabetes-associated gene variants in pancreatic beta cell function. PNAS 102 4807-4812.

Nordeen SK, Green PP 3rd \& Fowlkes DM 1987 A rapid, sensitive, and inexpensive assay for chloramphenicol acetyltransferase. DNA 6 173-178.

Odagiri H, Wang J \& German MS 1996 Function of the human insulin promoter in primary cultured islet cells. Journal of Biological Chemistry 271 1909-1915.

Oetjen E, Grapentin D, Blume R, Seeger M, Krause D, Eggers A \& Knepel W 2003 Regulation of human insulin gene transcription by the immunosuppressive drugs cyclosporin $\mathrm{A}$ and tacrolimus at concentrations that inhibit calcineurin activity and involving the transcription factor CREB. Naunyn Schmiedeberg's Archives of Pharmacology 367 227-236.

Ohlsson H, Karlsson K \& Edlund T 1993 IPF1, a homeodomaincontaining transactivator of the insulin gene. EMBO Journal 12 4251-4259.

Okita K, Yang Q, Yamagata K, Hangenfeldt KA, Miyagawa J, Kajimoto Y, Nakajima H, Namba M, Wollheim CB, Hanafusa T et al. 1999 Human insulin gene is a target gene of hepatocyte nuclear factor-1 alpha (HNF-1 alpha) and HNF-1 beta. Biochemical and Biophysical Research Communications 263 566-569.

Peers B, Leonard J, Sharma S, Teitelman G \& Montminy MR 1994 Insulin expression in pancreatic islet cells relies on cooperative interactions between the helix loop helix factor E47 and the homeobox factor STF-1. Molecular Endocrinology 8 1798-1806.

Peshavaria M, Gamer L, Henderson E, Teitelman G, Wright CV \& Stein R 1994 XIHbox 8, an endoderm-specific Xenopus homeodomain protein, is closely related to a mammalian insulin gene transcription factor. Molecular Endocrinology 8 806-816.

Peshavaria M, Henderson E, Sharma A, Wright CV \& Stein R 1997 Functional characterization of the transactivation properties of the PDX-1 homeodomain protein. Molecular and Cellular Biology 17 3987-3996.
Petersen HV, Serup P, Leonard J, Michelsen BK \& Madsen OD 1994 Transcriptional regulation of the human insulin gene is dependent on the homeodomain protein STF1/IPF1 acting through the CT boxes. PNAS 91 10465-10469.

Pino MF, Ye DZ, Linning KD, Green CD, Wicksteed B, Poitout V \& Olson LK 2005 Elevated glucose attenuates human insulin gene promoter activity in INS-1 pancreatic beta-cells via reduced nuclear factor binding to the A5/core and Z element. Molecular Endocrinology 19 1343-1360.

Qiu Y, Guo M, Huang S \& Stein R 2002 Insulin gene transcription is mediated by interactions between the $\mathrm{p} 300$ coactivator and PDX-1, BETA2, and E47. Molecular and Cellular Biology 22 412-420.

Read ML, Clark AR \& Docherty K 1993 The helix-loop-helix transcription factor USF (upstream stimulating factor) binds to a regulatory sequence of the human insulin gene enhancer. Biochemistry Journal 295 233-237.

Sander M, Griffen SC, Huang J \& German MS 1998 A novel glucose-responsive element in the human insulin gene functions uniquely in primary cultured islets. PNAS 95 11572-11577.

Schreiber E, Matthias P, Muller MM \& Schaffner W 1989 Rapid detection of octamer binding proteins with 'mini-extracts', prepared from a small number of cells. Nucleic Acids Research 176419.

Serup P, Jensen J, Andersen FG, Jorgensen MC, Blume N, Holst JJ \& Madsen OD 1996 Induction of insulin and islet amyloid polypeptide production in pancreatic islet glucagonoma cells by insulin promoter factor 1. PNAS 93 9015-9020.

Sharma A \& Stein R 1994 Glucose-induced transcription of the insulin gene is mediated by factors required for beta-cell-typespecific expression. Molecular and Cellular Biology 14 871-879.

Sharma A, Fusco-DeMane D, Henderson E, Efrat S \& Stein R 1995 The role of the insulin control element and RIPE3b1 activators in glucose-stimulated transcription of the insulin gene. Molecular Endocrinology 9 1468-1476.

Stein R 2001. In Handbook of Physiology Section 7: The Endocrine System, 1st edn, pp 25-47. Eds LS Jefferson \& HM Goodman. New York, NY, USA: Oxford University Press.

Walker MD, Edlund T, Boulet AM \& Rutter WJ 1983 Cell-specific expression controlled by the $5^{\prime}$-flanking region of insulin and chymotrypsin genes. Nature 306 557-561.

Watada H, Kajimoto Y, Miyagawa J, Hanafusa T, Hamaguchi K, Matsuoka T, Yamamoto K, Matsuzawa Y, Kawamori R \& Yamasaki Y 1996 PDX-1 induces insulin and glucokinase gene expressions in alphaTC1 clone 6 cells in the presence of betacellulin. Diabetes 45 1826-1831.

Watada H, Mirmira RG, Kalamaras J \& German MS 2000 Intramolecular control of transcriptional activity by the NK2-specific domain in NK-2 homeodomain proteins. PNAS 97 9443-9448.

Zhao L, Cissell MA, Henderson E, Colbran R \& Stein R 2000 The RIPE3b1 activator of the insulin gene is composed of a protein(s) of approximately $43 \mathrm{kDa}$, whose DNA binding activity is inhibited by protein phosphatase treatment. Journal of Biological Chemistry 275 10532-10537.

Zhao L, Guo M, Matsuoka TA, Hagman DK, Parazzoli SD, Poitout V \& Stein R 2005 The islet beta cell-enriched MafA activator is a key regulator of insulin gene transcription. Journal of Biological Chemistry 280 11887-11894.

Received 3 November 2005

Accepted 16 November 2005 